\title{
Assesment of prospective geological hazards in Torrevieja-La Mata coast (Western Mediterranean) based on Pleistocene and Holocene events
}

\section{Trinidad Torres}

Universidad Politecnica de Madrid Escuela Tecnica Superior de Ingenieros de Minas y Energia José E. Ortiz ( $\square$ joseeugenio.ortiz@upm.es )

Universidad Politecnica de Madrid Escuela Tecnica Superior de Ingenieros de Minas y Energia https://orcid.org/0000-0002-5699-2593

\section{Rosa Mediavilla}

Instituto Geológico y Minero de España: Instituto Geologico y Minero de Espana

\section{Yolanda Sánchez-Palencia}

Universidad Politecnica de Madrid Escuela Tecnica Superior de Ingenieros de Minas y Energia

Juan Ignacio Santisteban

Universidad Complutense de Madrid Facultad de Ciencias Geologicas

\section{Rogelio Vega-Panizo}

Universidad Politecnica de Madrid Escuela Tecnica Superior de Ingenieros de Minas y Energia

\section{Research Article}

Keywords: recent tectonics, coastal hazards, amino acid racemization, Glycymeris, Mediterranean

Posted Date: June 24th, 2021

DOl: https://doi.org/10.21203/rs.3.rs-581392/v1

License: (c) (i) This work is licensed under a Creative Commons Attribution 4.0 International License. Read Full License 


\section{Abstract}

The coastal zone in which the lagoons of La Mata and Torrevieja (Eastern Spain) developed can be described as a compilation of geo-hazards typical of the Mediterranean realm. This study has focused mainly on those linked to recent tectonics. Extensive use of the amino acid racemization dating method allowed us to establish the evolution of all the geomorphological units differentiated in the area, the most striking manifestation being at the La Mata Lagoon Bar, where MIS 5 deposits settled on MIS 7 sediments along a marked erosive unconformity, thereby attesting coastal uplift between these two stages. In addition, recent uplift processes were reflected on stepped abrasion platforms and, in some cases, enormous boulders were transported over these platforms by extreme surge waves. Furthermore, we obtained feasible evidence that, during the end of MIS 5, an earthquake with an offshore epicenter linked to Torrevieja Fault, Bajo Segura Fault or the set of faults linked to the former, was responsible for tsunami surge deposits represented in accumulations of randomly arranged and well preserved Glycymeris and Acanthocardia shells. Recent catastrophic effects linked to the earthquakes were also detected. In this regard, comparison of the paleontological and taphonomic analyses allowed us to discern between wave and tsunami surge deposits.

Therefore, evidence of these hazards undoubtedly points to important future (and present) erosive and/or catastrophic processes, which are enhanced by the presence of tourist resorts and salt-mining industry. Thus, these sites are also threatened by future increases in sea level in the context of warmer episodes, attested by raised marine fossil deposits. At the north of Cervera Cape, beaches will be eroded, without any possibility of sediment input from the starved Segura River delta. South of this cape, waves (and tsunamis) will erode the soft rocks that built up the cliff, creating deep basal notches and causing rockfall and the collapse of the overlying buildings.

\section{Introduction}

The area of Torrevieja-La Mata is subjected to active tectonic processes and the epicenters of many recent earthquakes have been in the inland and offshore surroundings of this zone. The largest tectonic event, named the "Torrevieja Earthquake", occurred on 21 March 1829 and registered an intensity of IX-X and magnitude of 6.5. This earthquake caused 389 deaths, injured 377 people and destroyed thousands of houses (2965). Indeed, it was the most devastating earthquake in Spanish history (Larramendi 1829). Earthquakes in this area are related to a series of known active faults which have controlled ground uplift or subsidence processes, sometimes coupled with changes in global sea level (Alfaro et al. 1995; Montenat et al. 1990; Martínez Solares and Mezcua Rodríguez 2002; Giménez et al. 2009). As in other Mediterranean regions, the occurrence of extreme events such as tsunamis and severe storms cannot be discarded (Silva et al. 1993; Somoza 1993; Dezileau et al. 2011; Shah-Hosseini et al. 2013, 2106; Deguara and Gauci 2017).

Therefore, the area of Torrevieja-La Mata has been affected by the activity of recent tectonics, producing earthquakes and with them erosive and depositional processes. Because the area is highly populated, as 
attested by the continuous development of tourist resorts, any tectonic event can have catastrophic effects. In this regard, it would be pertinent to have access to a realistic predictive model of future geological hazards. To this end, a complete geological and geomorphological framework of the area should be drawn up, including the characterization of the different deposits and related morphologies, discriminating between tectonic and/or climate forcings.

Raised marine deposits extend from the surroundings of the locality of Torrevieja to the Segura River mouth. The Cervera Cape acts as a geographical division: to the south, a lineal cliff extends southwards Torrevieja port interrupted by some marine deposits. There is a long sandy bar to the north, which protects the lagoons of La Mata and Torrevieja from wave influence. Of note, at the foot of Cervera Cape, there are two indurated coquina beds formed almost exclusively by Glycymeris nummaria shells, whose origin is discussed here.

Previous studies focused on the raised marine deposits of La Mata Bar (Somoza et al. 1986; Zazo et al. 1990). However, the area of Torrevieja-La Mata has never been examined in detail, despite being highly exposed.

In short, the aim of this study was 1) to establish the origin of some deposits in the area of Torrevieja-La Mata, discerning between two possible sources (surge storm vs. tsunami) based on the sedimentary architecture, fossil content and taphonomy, 2) to determine the age of these deposits and their relationship with other Pleistocene deposits in the area, through amino acid racemization dating, and 3 ) to obtain feasible information about the geological hazards of this highly populated flat coastal zone.

To put these deposits into context, relating them to structural elements (faults), our study addressed the whole area. Also, we compared the observations made in the raised marine deposits with those of an active beach, El Alquián, to the south of the province of Almería, with mollusc shell accumulations produced by wave action (storms) (Torres et al. 2013).

\section{Geographical And Geological Setting}

The study area is in the province of Alicante (Comunidad Autónoma de Valencia), in Southeastern Spain (Fig. 1). The area has two characteristic lagoons, Torrevieja $\left(14 \mathrm{~km}^{2}\right)$ and La Mata $\left(7 \mathrm{~km}^{2}\right)$, both unconnected to the Mediterranean sea, although the latter, a protected natural park, is connected to the sea along an artificial ditch (El Acequión). La Mata Lagoon feeds the salt works of Torrevieja Lagoon through an excavated ditch (Canal Salinero).

Both lagoons are slightly below sea level and separated by the Torrevieja hill (46 m.a.s.l.). The Rojales hill (127 m a.s.l), near the village of Rojales, separates La Mata Lagoon from the Segura River.

\subsection{Geology and tectonics}


From a regional point of view, the area of Torrevieja-La Mata is located in the Bajo Segura zone in the Eastern Betic realm, a diffuse collision area between the African and Iberian plates. The basin underwent NNW-SSE horizontal compression (Montenat et al. 1990; Alfaro et al. 1995) during the Alpine Orogeny and a series of loose folds control the structure of this area: the anticlines of Rojales and Torrevieja define the higher elevations while synclines host the lagoons of La Mata and Torrevieja (Fig. 2).

The sedimentary record is of Miocene-Quaternary age (Montenat 1973, 1977; Montenat et al. 1990). According to Martínez et al. (1977) and Almela et al. (1978), the most extensive deposits in the area belong to a diachronic unit named the Sucina Formation (Pliocene-Pleistocene), which comprises red muds and sands of alluvial origin, usually capped by a caliche (Montenat 1973). Towards its north boundary, near Rojales, Pliocene sands and muds of marine origin dominate.

Active strike-slip faults of regional development have been defined (Giménez et al. 2009; GarcíaMayordomo et al. 2012), namely Torrevieja (TF) and San Miguel (SMF), together with the reverse Bajo Segura Fault (BSF), which is one of the main active faults of the Eastern Betic Shear Zone (Alfaro et al. 2012), located at the northern boundary of the study area (Fig. 2). According to the Quaternary Faults Database of Iberia (QAFI, García Mayordomo et al. 2012), these faults are still active.

The activity of TF and SMF produced a raised block from Torrevieja to the south boundary of Cervera Cape and lowered one block on its northern edge, thus conditioning the present-day landscape (Silva et al. 1993).

The activity of these faults is reflected by the marked seismicity of the zone during historical times (Martínez Solares and Mézcua 2002). According to Somoza (1993), seismic activity in the area causes vertical movements of between 0.2 and $-0.2 \mathrm{~mm} /$ year. In 1829, an earthquake almost destroyed the village of Torrevieja. This was followed by a rapid drop in sea level and surges that destroyed fishing boats in the port. The earthquake also affected the local landscape, causing the Cervera Cape cliff to rise $20 \mathrm{~cm}$ and the appearance of a rift (Silva et al. 1993). The location of the epicenter of this earthquake has been a matter of discussion. Some authors have proposed that the activity of BSF was responsible (Somoza 1993; Sanz de Galdeano et al. 1995; Alfaro et al. 2002; García-Mayordomo and Martínez Díaz 2006; Giménez et al. 2009; Silva et al. 2017), while others (López Casado et al. 1992; Delgado et al. 1993) postulated that TF was the most probable source. Based on offshore geophysical research, Perea et al. (2012) did not discard an offshore epicenter, although the lack of tsunami-related deposits makes this scenario unlikely. Indeed, those authors described a normal fault swarm affecting Pleistocene deposits and even reaching the seafloor offshore of Cervera Cape.

\section{Material And Methods}

We build a Digital Terrain Model at different scales to gain an accurate view of the geomorphology of the area, with special attention to the area of Cervera Cape Cliff (Fig. 1). Six distinct units can be distinguished from the geomorphological perspective: Torrevieja Glycymeris Bed (TOG), Torrevieja Cliff (TOC), Cervera Cape Cliff (CCC), Cervera Cape Glycymeris bed (CCG), La Mata Bar (LMB) and La Mata 
Lagoon (LML) (Fig. 1). We developed three fieldwork campaigns to obtain samples from the 6 geomorphological units for sedimentological and stratigraphical studies.

\subsection{Ancient deposits}

In CCG and TOG, we performed a detailed survey of the paleontological content, preservation and arrangement. In this regard, we examined the bed surface, as well as all the exposures of its inner part along the abundant incisions (gullies) linked to current wave action, which allowed observation of the total thickness of this deposit. We recovered mollusc shells and examined their preservation. We also considered shell arrangements in order to identify the origin of these deposits.

Given that LMB deposits were studied in detail by Somoza et al. (1986) and Zazo et al. (1990), and in TOC and CCC erosive morphologies occurred, these localities were not sampled to study their palaeontological content.

\subsection{Recent deposits of El Alquián}

To characterize heavy-storm-linked mollusc taphonomy, and for comparison purposes with the Pleistocene deposits of CCG and TOG, we collected modern mollusc shells from $30 \mathrm{~m}^{2}$ of El Alquián beach, in Almería (SE Spain), just after a period of heavy winter surge (Fig. 4G, H). All shell remains up to a depth of $5 \mathrm{~cm}$ were recovered and identified at species level. This relatively remote area was chosen due to the low impact of tourism. We recovered a total of 1,604 shells from these beach deposits. The preservation of each Glycymeris shell examined. For species identification, we used the atlases of D’Angelo and Gargiullo (1987), Gofas et al. (1991), Salas et al. (1991), Giannuzzi Savelli et al. (1997) and Nolf and Swinnen (2013).

\subsection{Datings}

To obtain a chronological framework of the geological processes that determined the geomorphological evolution of the area, 15 Glycymeris shells from CCG were sampled for amino acid racemization dating. To avoid recent contamination (recent algae and/or decay products of other organisms), shells were picked as far as possible from the sea. Two $P$. latus specimens were also recovered for analysis.

We recovered and analyzed a similar number of Glycymeris shells at LMB sites: 9 samples from the ancient Roman port (LMB-1) and 5 from LMB-2. We also selected 20 Glycymeris shells from TOG and recovered samples (5 Glycymeris shells) from the megadune exposed at CCC, which comprises bioclastic sands and some beds are visibly made of thin wind-glided pelecypod shell fragments. We also took 2 samples of Vermetidae shells from an isolated large angular boulder lying on the intermediate platform of CCC.

Deposits of LML were sampled at the mouth of El Acequión ditch. For this purpose, we used a gaspowered Wacker $\mathrm{BH}-23$ jackhammer to drill two 2-m long boreholes with continuous core recovery, named 
LML-A and LML-B. We refer to the horizons of the cores by their depth (in $\mathrm{cm}$ ) from top to bottom (e.g., level LML-A-80 is at $80 \mathrm{~cm}$ ).

Core samples were examined for a sedimentological study and ostracode and gastropod shell recovery. Samples were washed and sieved at $63 \mu \mathrm{m}$, and carapaces and shells were recovered under a binocular microscope.

\subsubsection{Amino acid racemization}

A hollow diamond drill was used to remove a discoid sample (8 $\mathrm{mm}$ in diameter) from an area close to the beak of the Glycymeris shells recovered from TOG, CCC, CCG, LMB-1 and LMB-2. A 25-mm diameter discoid sample was obtained from the ventral side of the last whorl of $P$. latus shells from CCG using a hollow diamond drill, and a small sample near the aperture of gastropod shells belonging to the Helicidae family were recovered from LML. In all cases, peripheral parts (approximately 20-30\%) were removed after chemical etching with $2 \mathrm{~N} \mathrm{HCl}$. Afterwards, $10-20 \mathrm{mg}$ of samples were selected for amino acid racemization analysis.

Ostracode valves from LML cores were carefully cleaned by sonication in DDI water and rinsed to remove sediment. Some valves were cleaned with a small brush under a binocular microscope to eliminate fine debris. To remove secondary organic molecules adsorbed to the valves, they were submerged in $3 \%$ hydrogen peroxide $\left(\mathrm{H}_{2} \mathrm{O}_{2}\right)$ for $2 \mathrm{~h}$ following Kaufman (2000) and Hearty et al. (2004).

Amino acid concentrations and $D / L$ values were quantified using a high-performance liquid chromatograph (HPLC) in the Biomolecular Stratigraphy Laboratory, following the sample preparation protocol described by Kaufman and Manley (1998) and Kaufman (2000). This procedure involves hydrolysis, which was performed under an $\mathrm{N}_{2}$ atmosphere in $7 \mathrm{~mL}$ of $6 \mathrm{M} \mathrm{HCl}$ for $20 \mathrm{~h}$ at $100^{\circ} \mathrm{C}$. The hydrolyzates were evaporated to dryness in vacuo and then rehydrated in $7 \mathrm{~mL} 0.01 \mathrm{M} \mathrm{HCl}$ with $1.5 \mathrm{mM}$ sodium azide and $0.03 \mathrm{mM}$ Lhomo-arginine (internal standard). Samples were injected into an Agilent1100 HPLC equipped with a fluorescence detector. Excitation and emission wavelengths were programmed at $335 \mathrm{~nm}$ and 445, respectively. A Hypersil BDS C18 reverse-phase column ( $5 \mathrm{~mm} ; 250 \mathrm{~mm}$; $4 \mu \mathrm{m}$ i.d.) was used for the separation. Derivatization occurred before injection by mixing the sample ( 2 $\mathrm{mL}$ ) with the pre-column derivatization reagent $(2.2 \mathrm{~mL})$, which comprised $260 \mathrm{mM}$ isobutyryl-L-cysteine (chiral thiol) and $170 \mathrm{mM}$ o-phthaldialdehyde, dissolved in $1.0 \mathrm{M}$ potassium borate buffer-solution at $\mathrm{pH}$ 10.4. Eluent $A$ consisted of $23 \mathrm{mM}$ sodium acetate with $1.5 \mathrm{mM}$ sodium azide and $1.3 \mathrm{mM}$ EDTA, adjusted to $\mathrm{pH} 6.00$ with $10 \mathrm{M}$ sodium hydroxide and $10 \%$ acetic acid. Eluent $\mathrm{B}$ was HPLC-grade methanol, and eluent $C$ consisted of HPLC-grade acetonitrile. A linear gradient was performed at 1.0 $\mathrm{mL} / \mathrm{min}$ and $25^{\circ} \mathrm{C}$, from $95 \%$ eluent $A$ and $5 \%$ eluent $B$ upon injection to $76.6 \%$ eluent $A, 23 \%$ eluent $B$, and $0.4 \%$ eluent $C$ at $31 \mathrm{~min}$. This approach allowed the separation of aspartic acid (Asx), glutamic acid (Glx), serine (Ser), glycine (Gly), alanine (Ala), valine (Val), phenylalanine (Phe), isoleucine (lle), leucine (Leu), threonine (Thr), arginine (Arg) and tyrosine (Tyr). Age was determined using the age calculation algorithms for ostracode shells described by Ortiz et al. $(2004 a, b)$. 


\section{Results}

\subsection{Geomorphological Units}

The geological characteristics of the 6 geomorphological units are described below.

\section{Torrevieja Glycymeris Bed (TOG)}

It consists of a relic of an originally larger reddish bed containing well-preserved Glycymeris and Acanthocardia shells randomly oriented in a sandy matrix that shows carbonate cementation. It is 20-50 $\mathrm{cm}$ above sea level and developed above red alluvial materials, formerly named the Sucina Formation (Montenat 1973).

\section{Torrevieja Cliff (TOC)}

This area has a thick bed (caliche) covering reddish alluvial deposits of Pliocene-Pleistocene age belonging to the Sucina Formation (Fig. 3A), and erosive notches are present. Wave erosion frequently causes rock falls and large boulders accumulate at foot of the cliff. An active abrasion platform is visible and the narrow beach is gravelly.

Cervera Cape Cliff (CCC)

This area has indurated eolian sediments, which, according to Almela et al. (1978), and also based on the amino acid racemization ages presented below, are of Pleistocene age, although Silva et al. (2019) suggested a Pliocene age. The sand cosets are 2-3 $\mathrm{m}$ high and dip backshore, marking the dune movements. The sand-sized particles are carbonate in nature, quartz is not abundant and, in some cases, cross-beds comprise almost exclusively granuli of shell bioclasts (Fig. 3B). The eolian complex is capped by a thick caliche.

These eolian deposits constituted form a cliff produced by wave erosion, which provides an excellent perspective of the inner organization of the deposits. Indeed, three stepped wave abrasion surfaces at 4, 1 and $0 \mathrm{~m}$ a.s.I. are visible in this area (Fig. 3C, D; Fig. 5). The flattened abrasion platforms do not show sediment accumulation, probably due to the poor cementation of the eolian sandstones, which easily disaggregate. Diverse faults can be observed. Indeed, the cliff is crossed by a long fault (Fig. 5), which might correspond to the "grieta" (crack) that opened after the 1829 earthquake described by Larramendi (1829).

At the foot of the cliff there is a chaotic accumulation of fallen sandstone boulders (Fig. 3B). Of note, an angular boulder $\left(>2 \mathrm{~m}^{3}\right)$ on the intermediate platform shows abundant holes drilled by Lithophaga lithophaga, which, in some cases, remain in life position, as well as some tens of Vermetidae shells that attest that it was underwater before being lifted to the platform (Fig. 3E, F).

Cervera Cape Glycymeris bed (CCG) 
This area attracted the attention of researchers (Montenat 1977; Somoza et al. 1986; Zazo et al. 1990) because of the presence of representatives of Tyrrhenian fauna. However, the unusual sedimentological characteristics have never been described.

CCG appears as an isolated cemented blanket made of a myriad of disarticulated Glycymeris bimaculata shells at 20-50 m a.s.I (Fig. 3G). The relic outcrop is $350 \mathrm{~m}$ long (SE-NW) and $50 \mathrm{~m}$ wide (E-W).

Northwards, it was wiped out by recent erosion. The shell bed lies on scoured reddish sediments from the Sucina Formation (Fig. 3H). It is $25-35 \mathrm{~cm}$ thick and dips gently seawards. Wave erosion produced gullies, which allow observation of the internal architecture. At its rear, there are loosely cemented dune sands, intensely bioturbated by plant roots.

According to the field observations, CCG is a biorudite with a sandy-silty matrix and carbonate cement. In the inner part of the bed, Glycymeris shells appear randomly oriented, and vertical arrangements are also common, in some cases, adopting a steep stacking pattern, like plates in a dishwasher (Fig. $3 \mathrm{H}$ ). Shells at the top of CCG show a horizontal arrangement, either concave-up or concave-down. Of note, there are a number of "alien boulders" made of a coquina of small pelecypods (Fig. 4A). At the top of CCG, we detected five shells belonging to large gastropods (3 Persististrombus latus (Strombus bubonius), 2 Stramonita (Thais) haemastoma). These shells are poorly preserved, being deeply eroded and broken in such a way that only fragments of the last whorl or the columella are observable (Fig. 4B). These shells contrast with the pristine appearance of Glycymeris and Acanthocardia shells.

La Mata Lagoon Bar (LMB)

This bar, which consists of fossiliferous sandy beds, extends northwards from CCG and closes off La Mata Lagoon. Somoza et al. (1986) and Zazo et al. (1990) gave a detailed description of the sedimentary architecture of $L M B$, interpreting that these deposits corresponded to a sandy bar, but the paleontological content was only briefly commented on. It was assumed to be of Tyrrhenian age, as reflected by the presence of $P$. latus. Of note, we observed abundant Glycymeris spp. shells scattered in a bioclastic sand matrix and horizontally arranged.

Many years ago, a ditch (El Acequión) was excavated to feed La Mata Lagoon. Today the ditch is covered by concrete aas well as the ancient fossil dune cap to allow the development of a tourist resort. Near the entrance to the ditch, there was an ancient Roman Port constructed on this bar (LMB-1) (Fig. 4C, D). South of this port, there were other deposits with abundant shell remains (LMB-2) (Fig. 4E). Indeed, Somoza et al. (1986) identified two bar systems (Fig. 6) caused by the development of a marked erosive surface separating a lower unit of unknown age (which corresponded to LMB-1) from the overlying one with the presence of $P$. latus (LMB-2).

La Mata Lagoon (LML)

At the point where the ditch (El Acequión) entered LML, it is possible to observe nine beds made of alternating sands and muds with abundant articulated shells of pelecypods and also gastropods 
(Fig. 4F). The maintenance works to clean the ditch of collapsed walls facilitated sample collection.

\subsection{Chronology}

The mean D/L values of three amino acids (Ile, Asx and GIx) in Glycymeris shells of TOG, CCC, CCG and LMB are given in Table 2. We focused on these amino acids as Asx and Glx are the most abundant in this genus (cf. Demarchi et al. 2015), while lle is the amino acid most commonly used for dating purposes in this genus (Belluomini et al. 1986, 1993; Hearty 1986, 1987; Hearty et al. 1986; Torres et al. 2000, 2010, 2013; Ortiz et al. 2004b).

Table 2

Mean $D / L$ values of isoleucine, aspartic acid, glutamic acid obtained in $G$. nummaria and $P$. latus shells and Vermetidae of the different localities. D-Allo/L-lle values, which were analyzed in HPLC, are presented as equivalent GC values.

\begin{tabular}{|lllllll|}
\hline Site & Taxa & N & D-alle/L-lle & D/L Glu & D/L Asx & Age \\
\hline TOG & G. nummaria & 20 & $0.491 \pm 0.050$ & $0.461 \pm 0.039$ & $0.636 \pm 0.046$ & MIS 5 \\
CCG & G. nummaria & 15 & $0.468 \pm 0.046$ & $0.464 \pm 0.053$ & $0.582 \pm 0.071$ & MIS 5 \\
CCG & P. latus & 3 & $0.492 \pm 0.126$ & $0.262 \pm 0.022$ & $0.455 \pm 0.002$ & MIS 5 \\
CCC & G. nummaria & 5 & $0.503 \pm 0.036$ & $0.397 \pm 0.063$ & $0.569 \pm 0.054$ & MIS 5 \\
\hline CCC boulder & Vermetidae & 2 & - & $0.060 \pm 0.003$ & $0.108 \pm 0.001$ & MIS 1 \\
\hline LMB-1 & G. nummaria & 9 & $0.579 \pm 0.052$ & $0.465 \pm 0.104$ & $0.610 \pm 0.111$ & MIS 5 \\
\hline LMB-2 & G. nummaria & 5 & $0.660 \pm 0.066$ & $0.480 \pm 0.039$ & $0.740 \pm 0.037$ & MIS 7 \\
\hline
\end{tabular}

For Ile, the values obtained by HPLC and IE-LC required conversion in order to be compared with D-alle/Llle values measured by gas chromatography (GC) (cf. Ortiz et al. 2004b). This conversion was supported by the analysis of samples from an inter-laboratory comparison (ILC) exercise (cf. Wehmiller 1984; Torres et al. 1997; Wehmiller et al. 2010). The lle epimerization (D-alle/L-lle) values, ranging between 0.45 and 1.1 by IE-LC and HPLC, were approximately 0.10 lower than those obtained by GC, i.e., D-alle/L-lle $e_{G C}=$ Dalle/L-Ile $\mathrm{HPLC}_{\mathrm{HE}-\mathrm{LC}}+0.10$. For lower D-alle/L-Ile values, the difference was between 0 and 0.05 .

Asx and GIx D/L values calculated by HPLC can be compared directly with those obtained by GC because of the similarities found between the racemization ratios of the samples from Wehmiller's (1984) ILC exercise and several samples analyzed by GC and HPLC in our laboratory (Ortiz et al. 2004b, 2009).

The samples from LMB-1, CCG and TOG showed similar racemization and epimerization values as those from raised marine terraces of MIS 5e age (Aminozone E of Hearty et al. 1986; Hearty 1987). Similar D/L values were also reported by Torres et al. $(2000,2010,2016)$ and Ortiz et al. (2017) for MIS 5 deposits in the Mediterranean realm. In contrast, samples from LMB-2 showed similar D/L values and correlated with MIS 7 (Aminozone F of Hearty et al. 1986; Hearty 1987). It is important to note that Asx D/L values did not perform as well as Ile and Glx in the dating of raised marine deposits in the Iberian Peninsula, as 
pointed out by Torres et al. (2000). In fact, Asx shows a higher racemization rate than lle and Glx in land snails (Goodfriend 1991; Goodfriend and Meyer 1991) and marine molluscs (Kvenvolden et al. 1979; Lajoie et al. 1980; Kimber and Griffin 1987).

Indeed, consistent with the findings of other studies (Hearty 1986, 1987; Hearty et al. 1986; Torres et al. $2000,2010,2013)$, we observed that lle epimerization analysis showed a greater capacity to discriminate between Pleistocene sites of distinct ages than Glx and Asx, as closer Asx and Glx D/L values were obtained for MIS 5, MIS 7 and MIS 11 localities than D-alle/L-lle values.

For $P$. latus samples from CCG (Table 2), we compared the D/L values with those obtained from sites in Tunisia and Spain (Hearty 1986; Torres et al. 2010, 2013). We found that they belonged to MIS 5. No further age-accuracy than Stage level could be established.

The mean $D / L$ values and standard deviations of ostracodes of each horizon from cores drilled in $L M L$ are shown in Table 3. Asx and GIx D/L values were selected for the age calculation because they account for over ca $50 \%$ of the amino acid content in most of these valves (Kaufman 2000; Bright and Kaufman 2011). The numerical age of each bed was determined by introducing the Asx and GIX D/L values obtained in ostracode valves collected at each level into the age calculation algorithms established by Ortiz et al. (2004a).

Table 3

Aspartic acid (Asx) and glutamic acid (GIx) D/L values in ostracode valves of $L M L$ cores (A and B) with their corresponding ages.

\begin{tabular}{|llllll|}
\hline Horizon & Genus & N & D/L Asx & D/L Glx & Age (ka) \\
\hline LML-A- 115 & Leptocythere & 2 & $0.408 \pm 0.014$ & $0.164 \pm 0.016$ & $170.8 \pm 13.8$ \\
\hline LML-A-140 & Leptocythere & 1 & 0.387 & 0.169 & $164.9 \pm 10.9$ \\
\hline LML-B-70 & Leptocythere & 1 & 0.472 & 0.232 & $252.5 \pm 3.3$ \\
\hline LML-B-75 & Leptocythere & 1 & 0.426 & 0.174 & $193.0 \pm 20.4$ \\
\hline LML-B-90 & Leptocythere & 1 & 0.483 & 0.175 & $223.4 \pm 60.9$ \\
\hline
\end{tabular}

In gastropod samples (Helicidae), the D/L values of Asx and Glx (Table 4) were introduced into the age calculation algorithms of Torres et al. (1997) for central and southern Iberian Peninsula.

Table 4

Aspartic acid (Asx) and glutamic acid (GIX) D/L values in gastropod (Helicidae) shells with their corresponding ages.

\begin{tabular}{|llllll|}
\hline Horizon & Taxa & N & D/L Asx & D/L Glu & Age \\
\hline LML-A-95 & Helicidae & 1 & 0.573 & 0.414 & $145.1 \pm 37.6$ \\
\hline LML-B-25 & Helicidae & 2 & $0.557 \pm 0.017$ & $0.387 \pm 0.030$ & $130.6 \pm 28.9$ \\
\hline
\end{tabular}


The age of a single bed is the average of the numerical dates obtained for each amino acid $D / L$ value measured in gastropods or ostracodes from that level, and the age uncertainty is the standard deviation of the numerical ages calculated at each level.

The amino acid $D / L$ values obtained in Vermetidae samples from a boulder on the intermediate abrasion platform of CCC were very low (Table 2). Although age calculation algorithms were not developed for this taxon, the low amino acid racemization values indicated a recent age, of only a few centuries or even younger.

\subsection{Taphonomy of El Alquián deposits}

\subsubsection{Diversity}

All the species identified in the deposits of El Alquián beach are listed in Table 1. Gastropods accounted for ca. $39 \%$ and pelecypods ca. $61 \%$. Among gastropods, representatives of the Muricidae and Thaididae families accounted for $63 \%$ of the whole sample, together with individuals of the species Cancellaria cancellata (7\%) (Table 1), although its presence is not usually common (D'Angelo and Gargiullo 1987). The remaining gastropod species (30\%) formed a short portfolio of common Mediterranean species. The pelecypod species were dominated by G. nummaria (dominant) and Glycymeris glycymeris, accounting for $74 \%$ of bivalves, followed far by Acanthocardia tuberculata-paucicostata.

Table 1

Mollusc species identified in El Alquián beach.

\begin{tabular}{|c|c|c|}
\hline Class & Taxa & $\%$ \\
\hline \multirow{2}{*}{$\begin{array}{l}\text { Gastropoda } \\
(39 \%)\end{array}$} & $\begin{array}{l}\text { Muricidae and Thaididade (Stramonita (Thais) haemastoma, Hexaples } \\
\text { trunculus, Murex brandaris), Cancellaridae (Cancellaria cancellata) }\end{array}$ & 70 \\
\hline & $\begin{array}{l}\text { Cerithium vulgatum, C. livulum, C. renovatum, Aporrhais pespelicani, Columbella } \\
\text { rustica, Conus mediterraneus, Osilinus (Phorcus) turbinatus-lineatus, Phalium } \\
\text { granulatum, Nassarius reticulatus, Luria lurida, Patella caerulea, P. } \\
\text { olyssiponensis, Phalium saburon, Fusinus sp., cf. Hecion peluucinum, Bolma } \\
\text { rugosa, Vermetus triquetus, Bulla striata, Ocenebra rugosa }\end{array}$ & 30 \\
\hline \multirow{3}{*}{$\begin{array}{l}\text { Pelecypoda } \\
(61 \%)\end{array}$} & Glycymeris glycymeris, G. nummaria & 74 \\
\hline & Acanthocardia tuberculata-paucicostata & 17 \\
\hline & $\begin{array}{l}\text { Chamelea gallina, Ostrea eulis, Donax semistriatus,Mactra stultorum, Arca noae, } \\
\text { Anomia ephippium, Pecten jacobaeus, Neopycnodente cochlear, Venus } \\
\text { verrucosa, Spondylus gaederopus. }\end{array}$ & 9 \\
\hline
\end{tabular}

With some negligible exceptions, all pelecypods were inhabitants of shallow waters with soft bottoms. Something similar occurred with the gastropod group, although Hexaples trunculus was an adaptative opportunistic wandering-in group predator (D’Angelo and Gargiullo 1987).

Thus, the mollusc content of El Alquián beach was characterized by high diversity ( 36 species), typical of surge wave deposits, with pelecypods predominating over gastropods. 
Moreover, the pelecypod shells appeared on the surface of the beach and showed a horizontal arrangement, either concave-up or concave-down, and they were rarely tilted, due to the presence of gravel particles forcing this position.

\subsubsection{Shell preservation}

Small gastropod shells were generally well preserved on El Alquián beach, whereas the largest ones (mostly H. trunculus) showed traces of abrasion and may have undergone depredation. To determine the preservation state of the shells, we followed Rogalla and Amler (2007). Thus, from a total of 1,100 Glycymeris and Acanthocardia shells, ca. 56\% showed strong evidence of erosion (Fig. 7A):

- $22 \%$ showed a deeply eroded umbo region, which progressed to form a hole, making them easy to be turned into beads.

- $24 \%$ showed broken shell margins and the fracture lines were smoothed by abrasion. Due to their thinness, the ventral borders of the shells were broken and/or abraded, to such an extent that we decided to measure the anteroposterior diameter of the shell.

- 10\% showed bioerosion (Clionia sp.) and/or bio-incrustation (serpulids).

\subsection{Taphonomy of TOG and CCG}

\subsubsection{Diversity}

In TOG and CCG, almost $95 \%$ of the faunal content corresponded to G. nummaria, with $A$. tuberculata being the associated species. A single well-preserved Trochidae specimen was the exception. Two highly eroded $P$. latus shells were found.

Furthermore, we observed that the shells were positioned on the top of the beds according to hydrodynamic factors: predominantly convex up, although in the inner part of the bed most shells were randomly oriented, and in stepped positions, they were even stacked vertically, like plates in a dishwasher.

\subsubsection{Preservation}

Following the criteria of Rogalla and Amler (2007), most of the shells from TOG and CCG were well preserved, as they did not show signs of erosion and were not broken (Fig. 7B), except for some specimens, in particular three $P$. latus shells, which were deeply eroded.

\section{Discussion}

Based on the ages obtained here, we can identify the following phases in the evolution of the TorreviejaLa Mata landscape:

1.-LMB was active during MIS 7, protecting pre-existing brackish pond deposits, as attested by the backbarrier deposits at the bottom of the LML cores, which were also dated at MIS 7. These deposits 
consisted of a series of foreshore dipping bioclastic sand cosets.

2.-During MIS 5 (probably MIS 5e) a new bar stacked on the former one, as Somoza et al. (1986) and Zazo et al. (1990) observed, showing a strongly marked erosive unconformity. This bar consisted of bioclastic sands forming foreshore dipping cosets (Fig. 6). As occurred in MIS 7, lagoonal deposits (LML) also appeared. According to Somoza et al. (1986), an erosive cliff (now covered by concrete) was visible at the back-bar, with fallen boulders present at its foot.

3.-During MIS 5, an earthquake with epicenter at the foreshore took place and was responsible for a tsunami of unknown energy that hit the unconsolidated MIS 5 bar, deeply reworking wave-transported and previously eroded $P$. latus shells, as well as angular boulders of bioclastic sandstones. Moreover, this tsunami wiped the seafloor, where a paucispeciphic thanatocoenosis made of disarticulated Glycymeris and Acanthocardia shells occurred, that were quickly transported to the shore, building a tabular coquina bed with randomly orientated shells (see Sect. 5.1).

4.-Associated with the general lowering of the sea level at the end of MIS 5 (Cawthra et al. 2018), the emerged former shoreface deposits were the sand and bioclast source of the CCC dunes. Indeed, some samples of small Glycymeris shells were dated at the end of MIS 5.

5. Samples from the top of short boreholes in LML revealed deposition during MIS 1. Thus, La Mata Lagoon also persisted during the Holocene, probably linked to the eustatic rise in the level of the Mediterranean sea at ca. 7.5-7.0 ka cal BP (Somoza et al. 1998; Zazo 1999, 2006; Zazo et al. 2003, 2008). 6.-Uplifts at the CCC footwall were responsible for stepped abrasion platforms and accumulation of fallen boulders. Moreover, the $D / L$ values obtained in Vermetidae samples from a large boulder in CCC point to the occurrence of a large storm/tsunami in recent times.

Thus, the major known effect of fault activity in this area was the destructive Torrevieja earthquake of 1829, although low-intensity earthquakes are continuously recorded. Our interpretation of CMG and CCG as tsunami deposits linked to TF, BSF or a set of marine faults implies that this geo-hazard has been present since at least the Upper Pleistocene times.

\subsection{Tsunami vs. storm deposits}

LMB deposits offer little doubt about their origin and have been widely described as sandy bars that protected and isolated the lagoonal deposits of LML (Somoza et al. 1986; Zazo et al. 1990). Likewise, the sandy deposits of CCC were previously interpreted to be of aeolian origin (Almela et al. 1978; Silva et al. 2019). In this regard, we dated the Glycymeris fragments of these deposits at MIS 5. These fragments accumulated to form a giant dune, covering La Mata anticline when the platform was exposed after regression.

The origins of CCG and TOG need prior considerations. It should be noted that Glycymeris species burrow to colonize wave-protected areas, with an average density of 1.6 individuals $/ \mathrm{m}^{2}$, have a life span of about 20 years, and are associated with a small number of other pelecypods (Peharda et al. 2010, 2012; Crncevic et al. 2013; Royer et al. 2013). Despite being protected from the normal wave regimen, Glycymeris shells can be moved towards the down-beach zone and later to the up-beach zone (transfer 
environment) during storms, finally reaching the beach-berm (sedimentary environment). Under "normal wave" conditions, some shells can be transported towards the shoreline, forming narrow rills at the bottom, which appear as lenticular bodies in the geological record (Muñoz and Udias 1991; Reinhard et al. 2006), and are abraded/broken at the surf zone.

The taphonomy of El Alquián beach, a resedimented entity, matched very well with the abovementioned characteristics: diversity of mollusc species with dominance of Glycymeris ssp. (pristine diversity), most shells being eroded and/or broken. The shells were horizontally arranged, with no differences between those positioned convex-up or convex-down. In this regard, LMB-1 and LMB-2 deposits showed these characteristics and were considered beach deposits.

In contrast, in CCG and TOG, species diversity was very low (95\% Glycymeris) and showed little fragmentation, chaotic arrangement of shells with elements oriented in a stepped manner $\left(>60^{\circ}\right)$ with respect to the stratification, and sharp shell fragments (not smoothly eroded by continuous wave abrasion). These findings are consistent with the criteria of Puga-Bernabeu and Aguirre (2017) for tsunamites.

It is unlikely that the Glycymeris shells of CCG and TOG broke during the rapid short transport over a sandy bottom, which deposited its load in a chaotic arrangement where shells did not present preferential orientation. The presence of "alien boulders" pulled from preexisting deposits reinforces this interpretation. The lack of bioerosion and encrustation support this hypothesis. The singularity of these deposits is reinforced by the absence of other marine sediments above and below them.

Therefore, the characteristics of CCG are similar to the sedimentological and paleobiological features of tsunami deposits rather than surge deposits (Dawson and Stewart 2007; Becker-Heiman et al. 2007; Donato et al. 2008; Engel and Brückner 2011; Smedile et al. 2011; Marriner et al. 2017; Mathes-Schmid et al. 2013; Puga-Bernabéu and Aguirre 2017). Thus, we tentatively interpret CCG and TOG deposits to be linked to a tsunami that occurred near the end of MIS 5, although we are also aware that this differentiation is a major challenge (Dawson and Stewart 2007; Engel and Brückner 2011) because of the influence of the boundary conditions.

In this case, the waves were generated not far from the coast and they swept the platform - the biosediment factory - transporting the shells and sand together. As occurs on dry land, a tabular coquina bed with randomly orientated shells built up. During the ebb, the shells on the bed were oriented and highly eroded older $P$. latus shells and rock fragments (angular boulders) from the pre-existing MIS 5 bar were reworked. In fact, this interpretation matches well with the opinion of Perea et al. (2012), who used marine geophysics to define a large number of faults affecting platform sediments of Pleistocene age in offshore area of La Mata-Torrevieja or even the present-day seafloor.

An important question is the location of the epicenter of the 1829 earthquake. Some authors place it in a distant area. Álvarez-Gómez et al. (2010) modelled that processes generated on the coast of Algeria would produce $30 \mathrm{~m}$ high tsunami waves in La Mata area, and Álvarez Gómez et al. (2011) modelled that earthquakes originating in the Alboran Sea would cause $0.5 \mathrm{~m}$ of maximum wave elevation in Torrevieja. In contrast, Muñoz et al. (1991) and García-Mayordomo and Martínez-Días (2006) situate the epicenter of the Torrevieja earthquake in a foreshore location. In this regard, TF, which extends $12 \mathrm{~km}$ on land and 12 km offshore (Fig. 2) (García Mayordomo and Martínez-Díaz 2006), has a strong seismogenic character 
(Rodríguez de la Torre 1984; Muñoz and Udías 1991; Albini and Rodríguez de la Torre 2001; Martínez Solares and Mézcua 2002). Similarly, BSF has an offshore prolongation (Alfaro et al. 2012; Silva et al. 2017) and a number of faults affect the platform sediments (Perea et al. 2012). In this regard, a coseismic regional rise linked to the Torrevieja earthquake has been described to have produced a $20 \mathrm{~cm}$ elevation in CCC (Silva et al. 2014, 2017, 2019).

We consider that a local source for the accumulation of CCG is more likely, probably associated with the activity of TF, as the low species diversity observed seemed to exclude a remote source such as Northern Algeria (Álvarez-Gómez et al. 2010), the Alboran Sea (Álvarez-Gómez et al. 2011) or the lbero-Maghrebian region (Muñoz et al. 1991). This tsunami swept the ramp where pelecypod (Glycymeris) shells accumulated and reached the previous MIS 5 e bar, leaving a shell bed inland after eroding the red alluvial muddy deposits (Sucina Formation) that appear on the waterline. The erosion of the MIS $5 e$ bar released some deeply abraded "alien" elements, which appeared at the top of the strata where the ebb arranged the shells in a normal position. Our interpretation of tsunami deposits linked to normal fault activity was supported by the recent work of Ott et al. (2011): after a modeling of an area with a scenario of plate collision, where reverse and normal faults coexist, the latter were responsible of a historical strong earthquake/tsunami event that affected the Crete island coast at $365 \mathrm{AD}$.

Thus, our observations support the notion that local sources of seismicity or the collision of the African and Iberian plates cause tsunami surges, which pose a serious threat to lowland tourist resorts and salt mining. Indeed, in the context of a recently approved ambitious resort project (at least 18 high rise buildings of 29 floors) for a wide area to the south of Cervera Cape, the seismic hazard should be taken into consideration.

\subsection{Other geological hazards}

In the Cervera Cape area, the evident interplay between coastal structure, sea-level changes and vertical motion of the land will complicate any coastal prospective study of geological hazards (Anzidei et al. 2014).

The ancient raised marine deposits observed in this area, located 1 to $4 \mathrm{~m}$ above sea level, attested past episodes of climate warming. Given the expected rise in sea level caused by human activity, which will alter the natural trend of a rise in the level of the Mediterranean during the Holocene (Vacchi et al. 2018), the whole area will be affected by associated geological hazards. In this regard, salt mining in Torrevieja Lagoon and the Natural Park of La Mata Lagoon, which are slightly below sea level, will be particularly affected.

At the uplifted Torrevieja Cliff (TOC), waves will cut back the cliff and notches in the cliff foot will favor gravitational processes, affecting the top-cliff shelter made of thick caliche deposits. At Cervera Cape Cliff (CCC), the rise in sea level would probably be reflected in the relative sinking of the recently elevated abrasion platforms, which will, in turn, allow surge waves to reach the foot of the cliff, thus accelerating rockfall and cliff retreat. In La Mata Bar (LMB) beach, the sand stripe is wider than in the southern part, although it can be considered to be in a starvation regime because the flow of the Segura River is almost negligible at its mouth and is unable to re-supply former sand deposits that have been washed seaward. Given that this coastal area is densely covered by housing developments, resorts, hotels and related 
services, as in many other Mediterranean areas, the local economy of the communities there could be severely damaged by seismic activity, increase in sea level and cliff retreat.

\section{Conclusions}

Here we combined a large number of amino acid racemization datings with paleontological, taphonomic and sedimentological analyses to obtain an accurate interpretation of geological hazards in a coastal area. Indeed, the paleontological and taphonomic analyses allowed us to identify tsunami-surge deposits under local paleoenvironmental conditions.

The Pleistocene evolution of the coast revealed that a series of very important processes took place during MIS 7 and MIS 5. The spatial relationship of these deposits with a bar dated at MIS 5 lying over ancient bar deposits of MIS 7 through erosive unconformity suggested elevation processes affecting the first one linked to recent tectonics. In this regard, based on the mollusc shell taphonomy of some raised deposits, the area studied showed evidence of a tsunami during MIS 5, with its epicenter near the coast, probably associated with TF, BSF or the set of faults linked to TF and affecting the seafloor. North of Cervera Cape, this tsunami was responsible for CCG deposits, which spread far into the hinterland. South of Cervera Cape, this event hit the cliff carved on the sediments of the Sucina Formation and deposited TOG.

TF and BSF controlled and continue to control the present-day morphology of the coast, driving the uplift of Cervera Cape at the south, while producing subsidence in the. Indeed, in the area of Cervera Cape, a continuous tectonic-related (earthquakes) uplift has been recorded, even in historical reports, confirming a true geological hazard. These normal faults caused the Torrevieja earthquake in 1829, the most destructive on record in Spain, although low-intensity earthquakes are registered continuously. The evidence of tsunami deposits (CCG, TOG) linked to these faults also during the Pleistocene implies that this hazard has been present over history.

In addition, raised marine deposits are widely spread in this area, being 1 to $4 \mathrm{~m}$ above the present sea level and attesting past episodes of climate warming. Given the predicted increase in sea level linked to global warming, new geological hazards are expected. At the south of Cervera Cape, the narrow beach at the cliff foot will disappear and the soft rocks of the foot of the cliff will be wave-eroded. Notch development will favor cliff plunging, associated with diverse subaerial mass movements (toppling, rock falls). Of note, the cliff top is densely populated.

Therefore, given that this area is highly populated and new resorts (high rise buildings of 29 floors) are planned, the seismic hazard should be taken into consideration. Thus, the area between Torrevieja and La Mata, as well as La Mata Lagoon (Natural Park) and the Torrevieja Lagoon saltworks could be strongly affected by earthquake-induced tsunamis, a rise in sea level, and cliff retreat, among other geological hazards. 


\section{Declarations}

\section{Acknowledgements}

This paper was made possible by funding from the Spanish Ministry of Science and Innovation project: Cambios ambientales y ocupación humana en el sector central del sureste ibérico (HAR2017-85726-C2-2P). We thant to the Department of the Ambient, Cambi Climatic i Desemvbolupament Rural of the Generalitat Valenciana that gave the work permission in the protected area, to Francisco José Martínez García Director of the Parque Natural de la lagunas de La Mata y Torrevieja and to Ana María Colominas Cloquell Technician of "Espacios Naturales del Parque Natural de Las Lagunas de la Mata y Torrevieja" as well as to the members of the Interpretation Center at la Mata.

\section{Contributions}

José E. Ortiz: Funding acquisition, Supervision, Writing - Review \& Editing; Trinidad Torres: Resources, investigation; Rosa Mediavilla: investigation, methodology; Yolanda Sánchez-Palencia: investigation, formal anaysis; José Ignacio Santisteban: investigation; Rogelio de la Vega: formal analysis

\section{Declaration of interests}

The authors declare that they have no known competing financial interests or personal relationships that could have appeared to influence the work reported in this paper.

\section{References}

1. Albini P, Rodríguez de la Torre FR (2001) The 1828-1829 earthquake sequence in the provinces of Alicante and Murcia (SE Spain): Historical sources and macroseismic intensity assessment. In: Glade T, Albini P, Francés F (eds) The Use of Historical Data in Natural Hazard Assessments. Springer, Dordrecht, pp 35-53

2. Alfaro García P, Doménech C, Estévez A, Soria JM (1995) Estructuras de deformación en sedimentos del Cuaternario reciente de la cuenca del Bajo Segura (Alicante). Discusión sobre su posible origen sísmico. Geogaceta 17:91-94

3. Alfaro P, Andreu JM, Delgado J, Estévez A, Soria JM, Teixidó T (2002) Quaternary deformation of the Bajo Segura blind fault (eastern Betic Cordillera, Spain) revealed by high-resolution reflection profiling. Geol Mag 139:331-341

4. Alfaro P, Bartolomé R, Borque M, Estévez A, García-Mayordomo J, García-Tortosa F, Gil A, Gràcia E, Lo lacono C, Perea H (2012) The Bajo Segura Fault Zone: Active blind thrusting in the Eastern Betic Cordillera (SE Spain). J Iber Geol 38:271-284

5. Almela A, Quintero I, Gómez-Nogueroles E, Mansilla H (1978) Hoja geológica Magna Guardamar de Segura (914). Instituto Geológico y Minero de España, Madrid 
6. Álvarez-Gómez JA, Olabarrieta M, González M, Otero L, Carreño E, Martínez-Solares JM (2010) The Impact of Tsunamis on the Island of Majorca induced by North Algerian Seismic Sources. Turkish $J$ Earth Sci 19:367-383

7. Álvarez-Gómez JA, Aniel Quiroga Í, González M, Otero Díaz LJ (2011) Tsunami hazard at the Western Mediterranean Spanish coast from seismic sources. Nat Hazards 11:227-240

8. Anzidei M, Lambeck K, Antonioli F, Furlani S, Mastronuzzi G, Serpelloni E, Vannucci G (2014) Coastal structure, sea-level changes and vertical motion of the land in the Mediterranean. Geol Soc London Spec Publ 388:453-479

9. Becker-Heidmann P, Reicherter K, Silva PG (2007) ${ }^{14}$ C-Dated Charcoal and Sediment Drilling Cores as First Evidence of Holocene Tsunamis at the Southern Spanish Coast. Radiocarbon 49(2):827-835

10. Belluomini G, Branca M, Delitala L, Pecorini G, Spano C (1986) Isoleucine Epimerization Dating of Quaternary Marine Deposits in Sardinia, Italy. Zeits Geomorph 62:109-117

11. Belluomini GL, Manfra A, Proposito (1993) Una recente aminocronologia dei depositi marini pleistocenici dell'area di Montalto di Castro e Tarquinia (Viterbo). II Quaternario 6:241-248

12. Bright J, Kaufman DS (2011) Amino acid racemization in lacustrine ostracodes, part l: effect of oxidizing pre-treatments on amino acid composition. Quat Geochronol 6:154-173

13. Cawthra HC, Jacobs Z, Compton JS, Fisher EC, Karkanas P, Marean CW (2018) Depositional and sealevel history from MIS 6 (Termination II) to MIS 3 on the southern continental shelf of South Africa. Quat Sci Rev 181:156-172

14. Crnčević M, Peharda M, Ezgeta-Balić D, Pećarević M (2013) Reproductive cycle of Glycymeris nummaria (Linnaeus, 1758) (Mollusca: Bivalvia) from Mali Ston Bay, Adriatic Sea, Croatia. Sci Mar 77:293-300

15. Dawson AG, Stewart I (2007) Tsunami deposits in the geological record. Sed Geol 200:166-183

16. D'Angelo G, Gargiullo S (1987) Guida alle conchiglie mediterranee: conoscerle, cercarle, collezionarle. Fabbri

17. Delgado J, Caturla JJG, Casado CL, Arguiñano CA (1993) Análisis de la respuesta del suelo en intensidades. Aplicación al terremoto de Torrevieja. V Reunión Nacional de Geología Ambiental y Ordenación del Territorio, Murcia, 1993: 627-636

18. Deguara JC, Gauci R (2017) Evidence of extreme wave events from boulder deposits on the southeast coast of Malta (Central Mediterranean). Nat Hazards 86:543-568

19. Demarchi B, Clements E, Coltorti M, can de Locht R, Kröger R, Penkman K, Rose J (2015) Testing the effect of bleaching on the bivalve Glycymeris. A case study of amino acid geochronology on key Mediterranean raised beach deposits. Quat Geochron 25:49-65

20. Dezileau L, Sabatier P, Blanchemanche P, Joly B, Swingedouw D, Cassou C, Castaings J, Martinez P, Von-Grafenstein U (2011) Intense storm activity during the Little Ice Age on the French Mediterranean coast. Palaeogeogr Palaeoclimatol Palaeoecol 299:289-297 
21. Donato SV, Reinhardt EG, Boyce JI, Rothaus R, Vosmer T (2008) Identifying tsunami deposits using bivalve shell taphonomy. Geology 36:199-202

22. Engel M, Brückner H (2011) The identification of palaeo-tsunami deposits-a major challenge in coastal sedimentary research. Coastline Reports 17:65-80

23. García-Mayordomo J, Insua-Arévalo J, Martínez-Díaz J, Jiménez-Díaz A, Martín-Banda R, MartínAlfageme S, Álvarez-Gómez J, Rodríguez-Peces M, Pérez-López R, Rodríguez-Pascua M, Masana E, Perea H, Martín-González F, Giner-Robles J, Nemser E, Cabral J, Compilers Q (2012) The Quaternary Active Faults Database of Iberia (QAFI v.2.0). J Iber Geol 38:285-302

24. García-Mayordomo J, Martínez-Díaz JJ (2006) Caracterización sísmica del anticlinorio del bajo segura (Alicante): fallas del Bajo segura, torrevieja y san miguel de salinas. Geogaceta 40:19-22

25. Giannuzzi-Savelli R, Pusateri F, Palmeri A, Ebreo C (1997) Atlante delle conchiglie marine del Mediterráneo, vol 2. Caenogastropoda parte 1. Edizioni de "La Conchiglia", Roma

26. Giménez J, Borque MJ, Gil AJ, Alfaro P, Estévez A, Suriñach E (2009) Comparison of long-term and short-term uplift rates along an active blind reverse fault zone (Bajo Segura, SE Spain). Stud Geophys Geod 53:81-98

27. Gofas S, Salas C, Moreno D (2011) Moluscos marinos de Andalucía volumen 1. Universidad de Málaga servicio de Publicaciones e intercambio científico

28. Goodfriend GA (1991) Patterns of racemization and epimerization of amino acids in land snail shells over the course of the Holocene. Geochim Cosmochim Acta 55:293-302

29. Goodfriend GA, Meyer V (1991) A comparative study of the Idnetics of amino acid racemization/epimerization in fossil and modera mollusk shells. Geochim Cosmochim Acta 55:3355-3367

30. Hearty PJ (1986) An inventory of last interglacial (sensu lato) age deposits from the Mediterranean Basin: a study of isoleucine epimerization and U-series dating. Z Geomorph NF Suppl-Bd 62:51-69

31. Hearty PJ (1987) New data on the Pleistocene of Mallorca. Quat Sci Rev 6:245-257

32. Hearty PJ, Miller G, Stearns C, Szabo BJ (1986) Aminostratigraphy of Quaternary shorelines in the Mediterranean basin. Geol Soc Am Bull 97:850-858

33. Hearty PJ, O'Leary MJ, Kaufman DS, Page MC, Bright J (2004) Amino acid geochronology of individual foraminifer (Pulleniatina obliquiloculata) tests, North Queenland margin, Australia: a new approach to correlating and dating Quaternary tropical marine sediment cores. Paleoceanography, 19 p. PA4022

34. Kaufman DS, Manley WF (1998) A new procedure for determining DL amino acid ratios in fossils using reverse-phase liquid chromatography. Quat Geochron 17:987-1000

35. Kaufman DS (2000) Amino acid racemization in ostracodes. In: Goodfriend GA, Collins MJ, Fogel ML, Macko SA, Wehmiller JF (eds) Perspectives in Amino Acids and Protein Geochemistry. Oxford University Press, New York, pp 145-160 
36. Kvenvolden KA, Blunt DJ, Clifton HE (1979) Amino-acid racemizarion in Quaternary shell deposits at Willapa Bay, Washington. Geochim Cosmochim Acta 43:1505-1520

37. Kimber RWL, Griffin CV (1987) Further evidence of the complexity of the racemization process in fossil shells with implications for amino acid racemization dating. Geochim Cosmochim Acta 51:839-846

38. Lajoie KR, Wehmiller JF, Kennedy GL (1980) Inter-and intrageneric trends in apparent racemization kinetics of amino acids in Quaternary mollusks. In: Hare PE, Hoering TC, Jing K Jr (eds) Biogeochemistry of Amino Acids. John Wiley, New York, pp 305-340

39. Larramendi JA (1829) Memoria y relación circunstanciada de los estragos que la terrible catástrofe de los terremotos de 21 de marzo y siguientes, principalmente el del Sábado. In: Santo 18 de abril hasta el presente día han causado en Torrevieja y demás pueblos de la Gobernación de Orihuela y sus inmediaciones, en la ciudad de Murcia y algunos pueblos de la provincia de este nombre. Imprenta Real, Madrid

40. López-Casado C. Peinado MA, Delgado J, Peláez JA, Fuentes C (1992) La serie sísmica de Torrevieja 1828-1829. Procedings of I Congreso Iberoamericano sobre técnicas aplicadas a la gestión de emergencias para la reducción de los desastres naturales. Universidad Politécnica de Valencia

41. Luque L, Lario J, Zazo C, Goy JL, Dabrio CJ, Silva PG (2001) Tsunami deposits as paleoseismic indicators: examples from the Spanish coast. Acta Geol Hisp 36:197-211

42. Martínez W, Nuñez A, Colodrón I (1977) Hoja geológica Magna Torrevieja (935). Instituto Geológico y Minero de España, Madrid

43. Martínez Solares JM, Mezcua Rodríguez J (2002) Catálogo sísmico de la Península Ibérica:(880 a. C1900). Instituto Geográfico Nacional, Madrid

44. Marriner N, Kaniewski D, Morhange C, Flaux C, Giaime M, Vacchi M, Goff J (2017) Tsunamis in the geological record: Making waves with a cautionary tale from the Mediterranean. Sci Adv 3:23752548

45. Mathes-Schmidt M, Schwarzbauer J, Papanikolaou I, Syberberg F, Thiele A, Wittkopp F, Reicherter K (2013) Geochemical and micropaleontological investigations of tsunamigenic layers along the Thracian Coast (Northern Aegean Sea, Greece). Zeits Geomorphol. Suppl Iss 57:5-27

46. Montenat C (1973) Les formations néogenes et quaternaires du Levant espagnol. Ph D Dissertation, University of Paris

47. Montenat C (1977) Les bassins néogènes du levant d'Alicante et de Murcia (Cordillères Bétiques orientales-Espagne). Stratigraphie, paléogéographie et évolution dynamique. Documents des Laboratoires de Géologie de la Faculté des Sciences de Lyon, Lyon

48. Montenat C, Ott d'Estevou PH, Coppier G (1990) Les bassins neógènes entre Alicante et Cartagena. Documents et travaux de l'Institut géologique Albert de Lapparent 12-13:313-368

49. Muñoz D, Udías A (1991) Three large historical earthquakes in Southern Spain. In: Mézcua J, Udías A (eds) Seismicity, Seismotectonics and Seismic Risk of the IberoMaghrebian Region. Publicaciones del Instituto Geográfico Nacional 8: 175-182

Page 20/31 
50. Nolf F, Swinnen F (2013) The Glycymeridae (Mollusca, Bivalvia) of the NE Atlantic and the Mediterranean Se. Neptunea 12:1-3

51. Ortiz JE, Torres T, Julià R, Llamas FJ (2004a) Algoritmos de cálculo de edad a partir de relaciones de racemización/epimerización de aminoácidos en pelecípodos marinos del litoral mediterráneo español. Rev Soc Geol Esp 17:217-227

52. Ortiz JE, Torres T, Juliá R, Delgado A, Llamas FJ, Soler V, Delgado J (2004b) Numerical dating algorithms of amino acid racemization ratios from continental ostracodes. Application to GuadixBaza basin (southern Spain). Quat Sci Rev 23:717-730

53. Ortiz JE, Torres T, Delgado A, Reyes E, Díaz-Bautista A (2009) A review of the Tagus river tufa deposits (central Spain): age and palaeoenvironmental record. Quat Sci Rev 28:947-963

54. Ortiz JE, Torres T, Sánchez-Palencia Y, Ferrer M (2017) Inter- and intra-crystalline protein diagenesis in Glycymeris shells: Implications for amino acid geochronology. Quat Geochron 41:37-50

55. Ott RF, Wegmann KW, Gallen SF, Pazzaglia FJ, Brandon MT, Ueda K, Fassoulas C (2021) Reassessing Eastern Mediterranean tectonics and earthquake hazard from the $365 \mathrm{CE}$ earthquake. AGU Advances 2: https://doi. org/10.1029/2020AV000315

56. Peharda M, Ezgeta-Balić D, Vrgoč N, Isajlović I, Bogner D (2010) Description of bivalve community structure in the Croatian part of the Adriatic Sea - hydraulic dredge survey. Acta Adriat 51:144-158

57. Peharda M, Crnčević M, Bušelić I, Richardson CA, Ezgeta-Balić D (2012) Growth and longevity of Glycymeris nummaria (Linnaeus, 1758) from the eastern Adriatic, Croatia. J Shellfish Res 31(4):947950

58. Perea H, Gràcia E, Alfaro P, Bartolomé R, Lo lacono C, Moreno X, Masana E, EVENT-SHELF Team (2012) Quaternary active tectonic structures in the offshore Bajo Segura basin (SE Iberian Peninsula - Mediterranean Sea). Nat Hazards Earth Sci Syst Sci 21:3151-3168

59. Puga-Bernabéu Á, Aguirre J (2017) Contrasting storm-versus tsunami-related shell beds in shallowwater ramps. Palaeogeogr Palaeoclimatol Palaeoecol 471:1-14

60. Reinhardt EG, Goodman BN, Boyce JI, Lopez G, van Hengstum P, Rink WJ, Raban A (2006) The tsunami of 13 December AD 115 and the destruction of Herod the Great's harbor at Caesarea Maritima, Israel. Geology 34:1061-1064

61. Rodriguez de la Torre F (1984) Los terremotos alicantinos de 1829. Publicaciones del Instituto de Estudios Alicantinos I 100:322

62. Rogalla NS, Amler MR (2007) Statistic approach on taphonomica phenomena in shells of Glycymeris glycymeris (Bivalvia: Glycymeridae) and its significance in the fossil record. Paläontol Zeits 81:334

63. Royer C, Thébault J, Chauvaud L, Olivier F (2013) Structural analysis and paleoenvironmental potential of dog cockle shells (Glycymeris glycymeris) in Brittany, northwest France. Palaeogeogr Palaeoclimatol Palaeoecol 373:123-132

64. Salas C, Gofas S, Moreno D (2011) Moluscos marinos de Andalucía volumen 2. Universidad de Málaga servicio de Publicaciones e intercambio científico 
65. Sanz de Galdeano CS, Casado CL, Delgado J, Peinado MA (1995) Shallow seismicity and active faults in the Betic Cordillera. A preliminary approach to seismic sources associated with specific faults. Tectonophysics 248(3-4):293-302

66. Shah-Hosseini M, Saleem A, Mahmoud AMA, Morhange C (2016) Coastal boulder deposits attesting to large wave impacts on the Mediterranean coast of Egypt. Nat Hazards 83:849-865

67. Shah-Hosseini M, Morhange C, De Marco A, Anthony EJ, Sabatier F, Mastronuzzi G, Pignatelli C, Piscitelli A (2013) Coastal boulders in Martigues, French Mediterranean: evidence for extreme storm waves during the Little Ice Age. Z Geomorphol 57:181-199

68. Silva PG, Goy JL, Somoza L, Zazo C, Bardají T (1993) Landscape response to strike-slip faulting linked to collisional settings: Quaternary tectonics and basin formation in the Eastern Betics, southeastern Spain. Tectonophysics 224:289-303

69. Silva PG, Rodríguez-Pascua MA, Giner-Robles JL, Pérez-López R, Lario J, Perucha MA, Bardají T, Huerta P, Roquero E, Bautista Dávila MB (2014). Catálogo de los efectos geológicos de los terremotos de España. Riesgos Geológicos y Geotecnia 4, Instituto Geológico y Minero de España, Madrid

70. Silva PG, Elez J, Giner-Robles JL, Rodríguez Pascua MA, Pérez-López R, Roquero E, Bardají T, Martínez-Graña AM (2017) ESI-07 ShakeMaps for instrumental and historical events in the Betic Cordillera (SE Spain): An approach based on geological data applied to seismic hazard. Quatern Int 451:185-208

71. Silva PG, Elez J, Giner-Robles JL, Pérez-López R, Roquero E, Rodríguez-Pascua MA, Bardají T, Martínez-Graña AM (2019) Análisis geológico del terremoto de Torrevieja de 1829 (Alicante, SE España). XV Reunión Nacional del Cuaternario, Bilbao, pp 434-437

72. Smedile A, De Martinia PM, Pantostia D, Bellucci L, Del Carlo P, Gasperini L, Pirrotta C, Poloni A, Boschia E (2011) Possible tsunami signatures from an integrated study in the Augusta Bay offshore (Eastern Sicily-Italy). Mar Geol 281:1-13

73. Somoza L (1993) Estudio del cuaternario litoral entre cabo de Palos y Guardamar (Murcia-Alicante). Las variaciones del nivel del mar en relación con el contexto geodinámico. PD Dissertation, Universidad Complutense de Madrid

74. Somoza L, Bardají T, Dabrio CJ, Goy JL, Zazo C (1986) Análisis de secuencias de islas barrera pleistocenas en relación con variaciones del nivel del mar, laguna de La Malta (Alicante). Acta Geol Hisp 21:151-157

75. Somoza L, Barnolas A, Arasa A, Maestro A, Rees JG, Hernández-Molina FJ (1998) Architectural stacking patterns of the Ebro delta controlled by Holocene high-frequency eustatic fluctuations, deltalobe switching and subsidence processes. Sed Geol 117:11-32

76. Torres T, Llamas JF, Canoira L, Coello J, García-Alonso P, Ortiz JE (2000) Aminostratigraphy of two marine sequences from the Mediterranean coast of Spain. Cabo de Huertas (Alicante) and Garrucha (Almería). In: Goodfriend GA, Collins MJ, Fogel ML, Macko SA, Wemiller JF (eds) Perspectives in Amino Acid and Protein Geochemistry. Oxford University Press, New York, pp 263-278 
77. Torres T, Llamas J, Canoira L, García-Alonso P, García-Cortés A, Mansilla H (1997) Amino acid chronology of the Lower Pleistocene deposits of Venta Micena (Orce, Granada, Andalusia, Spain). Org Geochem 26:85-97

78. Torres T, Ortiz JE, Arribas I (2013) Variations in racemization/epimerization ratios and amino acid content of Glycymeris shells in raised marine deposits in the Mediterranean. Quat Geochron 16:3549

79. Torres T, Ortiz JE, Arribas I, Delgado A, Julià R, Martín-Rubí JA (2010) Geochemistry of Persistrombus latus Gmelin from the Pleistocene Iberian Mediterranean realm. Lethaia 43:149-163

80. Torres T, Ortiz JE, Sánchez-Palencia Y (2016) Amino acid epimerization dating of Quaternary coastal deformation in SE Iberian Peninsula: the region between Aguas and Antas river mouths. C R Geosci 348:398-407

81. Vacchi M, Ghilardi M, Melis RT, Spada G, Giaime M, Marriner N, Lorscheid T, Morhange C, Burjachs F, Rovere A (2016) New relative sea-level insights into the isostatic history of the Western Mediterranean. Quat Sci Rev 201:396-408

82. Wehmiller JF, Miller G, de Vogel S, Kaufman DS, Bright J, Murray-Wallace CV, Ortiz JE, Penkman K (2010) Interlaboratory comparison of amino acid D/L values. Geol Soc Am 42:86

83. Wehmiller JF (1984) Interlaboratory comparison of amino acid enantiomeric ratios in fossil mollusks. Quat Res 22:109-120

84. Zazo C, Goy JL, Somoza L, Dabrio CJ (1990) Evolution of Barrier Island-Lagoon Systems from 200 KA Ago to the Present in the Littoral Zone of Alicante (Spain). Impact of a Probable Sea Level Rise In: Paepe R, Fairbridge RW, Jelsgersma S (eds) Greenhouse Effect, Sea Level and Drought. NATO ASI Series (Series C: Mathematical and Physical Sciences), Springer, Dordrecht. 325: 439-446

85. Zazo C (1999) Interglacial sea-levels. Quat Int 55:101-113

86. Zazo C (2006) Cambio climático y nivel del mar: la Península Ibérica en el contexto global. Cuat Geomorf 20:115-130

87. Zazo C, Dabrio CJ, Goy JL, Lario J, Cabero A, Silva PG, Bardaji T, Mercier N, Borja F, Roquero E (2008) The coastal archives of the last $15 \mathrm{ka}$ in the Atlantic-Mediterranean Spanish linkage area: sea level and climate changes. Quat Int 181:72-87

88. Zazo C, Goy JL, Dabrio CJ, Bardají T, Hillaire-Marcel C, Ghaleb B, González-Delgado JA, Soler V (2003) Pleistocene raised marine terraces of the Spanish Mediterranean and Atlantic coasts: records of coastal uplift, sea-level highstands and climate changes. Mar Geol 194:103-133

\section{Figures}




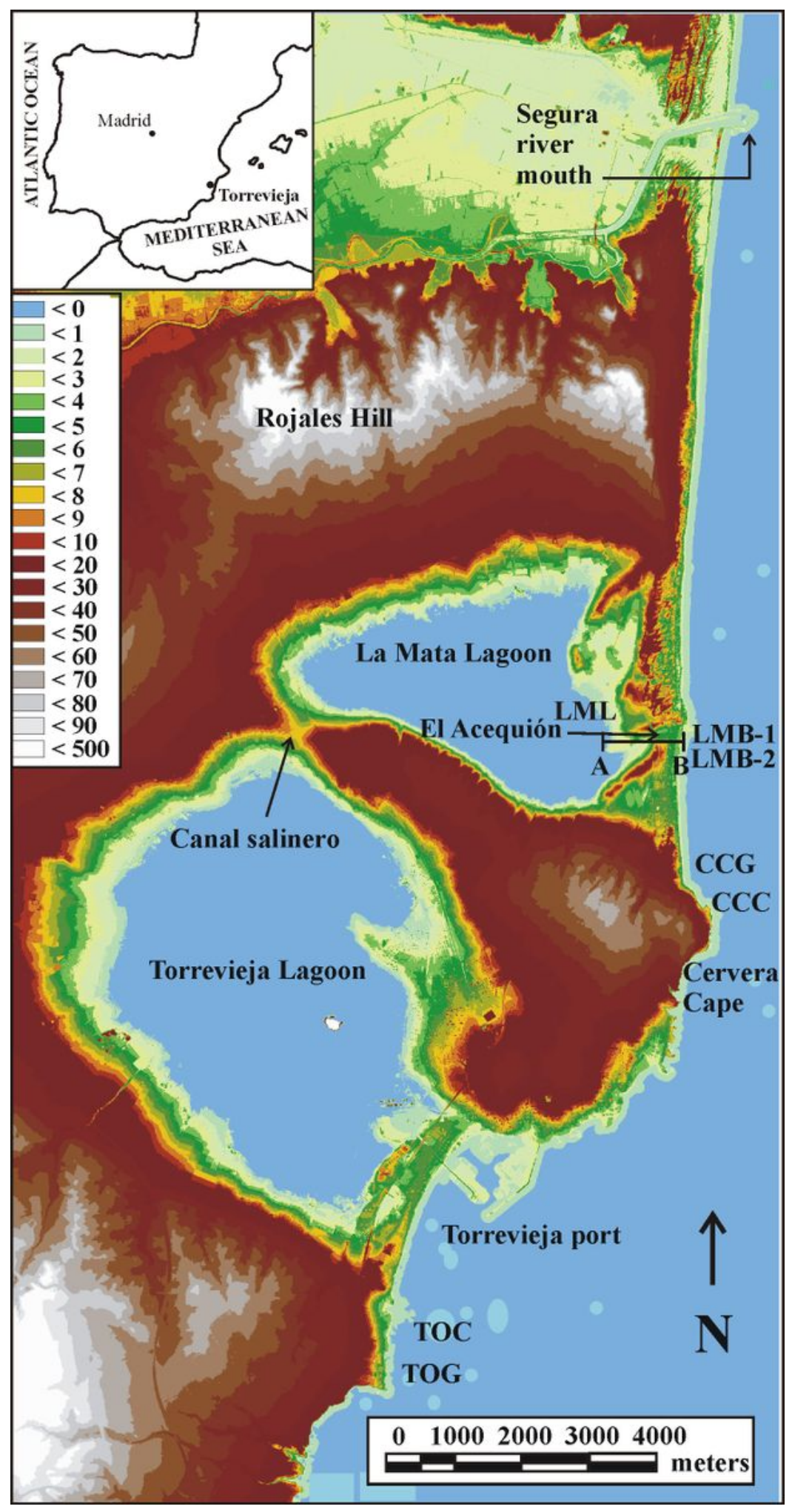

\section{Figure 1}

Digital Terrain Model of the study area: TOG (Torrevieja Glycymeris bed), TOC (Torrevieja Cliff), CCC (Cervera Cape Cliff), CCG (Cervera Cape Glycymeris bed), LMB- and LMB-2 (raised marine deposits of La Mata Bar); LML (La Mata Lagoon deposits). Section A-B described in Fig. 6 is shown. Note: The designations employed and the presentation of the material on this map do not imply the expression of any opinion whatsoever on the part of Research Square concerning the legal status of any country, 
territory, city or area o bbnhjr of its authorities, or concerning the delimitation of its frontiers or boundaries. This map has been provided by the authors.

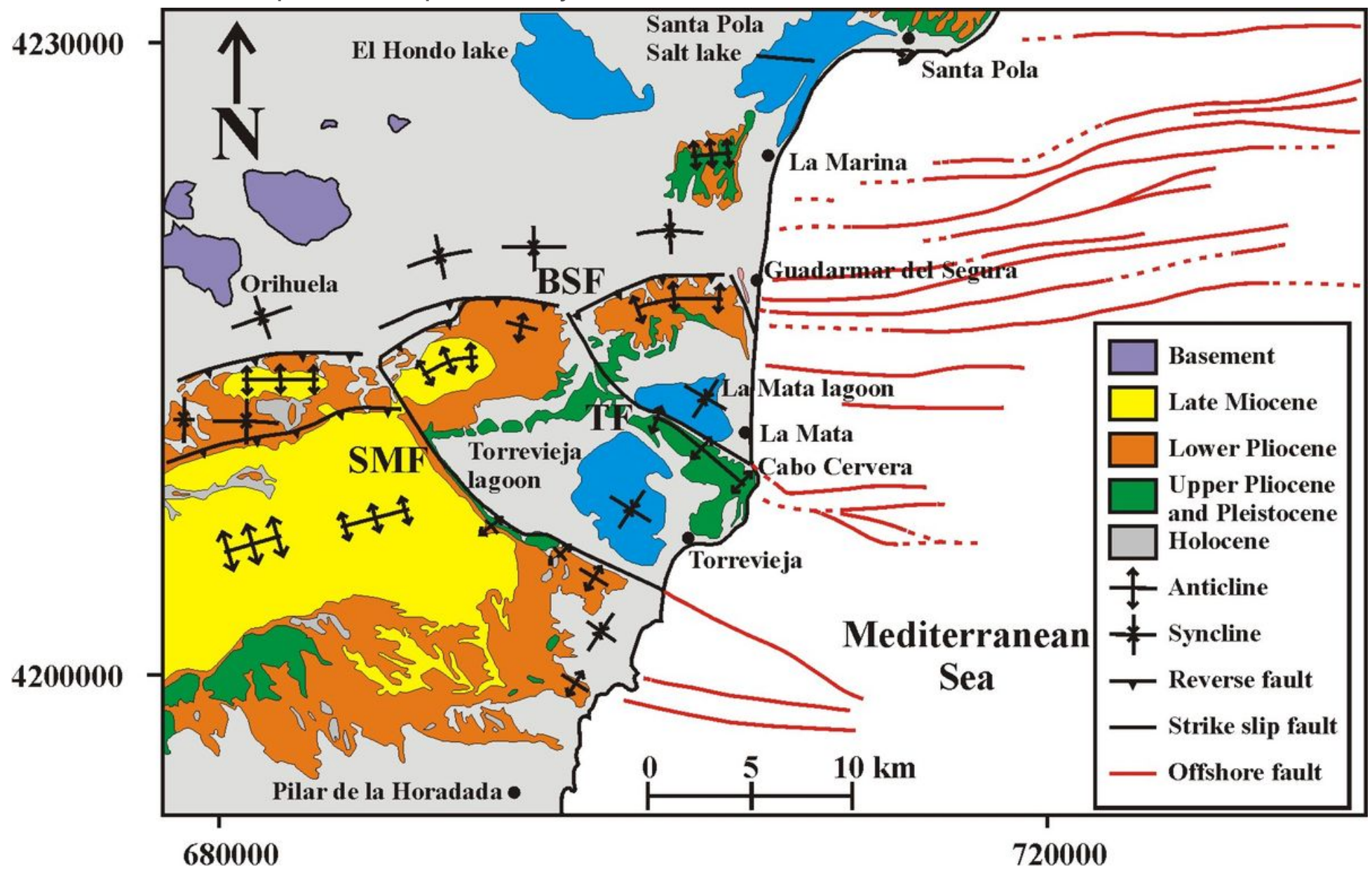

Figure 2

Geological map of Mazarrón (modified from Alfaro et al. 2012) with the location of the geomorphological units. The Torrevieja Fault (TF), San Miguel Fault (SMF) and Bajo Segura Fault (BSF) are shown. Note: The designations employed and the presentation of the material on this map do not imply the expression of any opinion whatsoever on the part of Research Square concerning the legal status of any country, territory, city or area o bbnhjr of its authorities, or concerning the delimitation of its frontiers or boundaries. This map has been provided by the authors. 

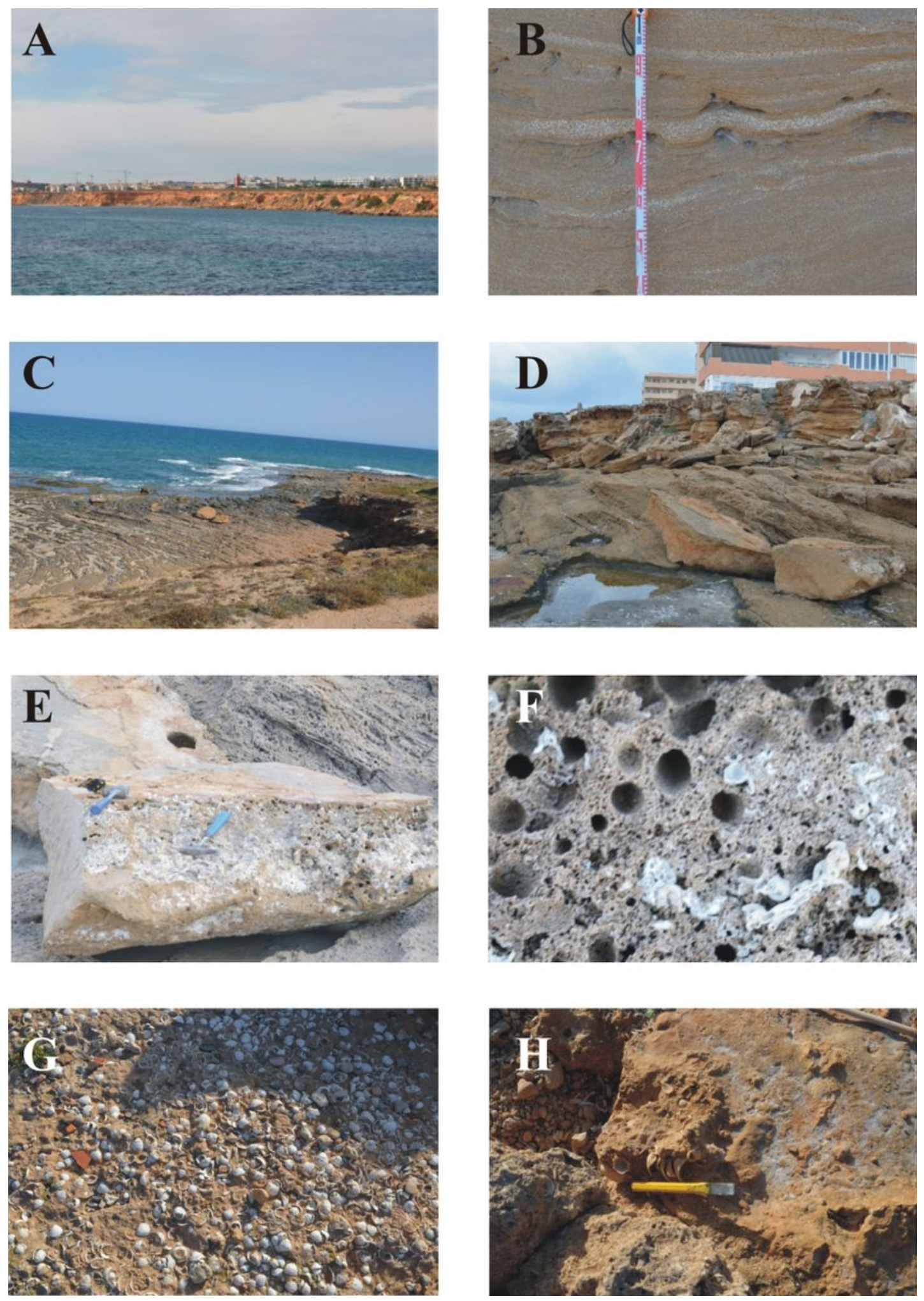

\section{Figure 3}

Representative photos of the Torrevieja-La Mata area: (A) Torrevieja Cliff from the sea; (B) Detailed view of the paleodune sets of Cervera Cape Cliff (CCC) made of shell fragments; (C) Lower abrasion platform of CCC with fallen boulders, the upper wave abrasion platform is observed in the foreground; (D) Intermediate and lower wave abrasion platforms of Cervera Cape; (E) Angular boulder on the intermediate platform of CCC with Lithophaga litophaga boreholes and incrusted Vermetidae; (F) Detailed view of the 
angular boulder of CCC; (G) Top of the Cervera Cape Glycymeris bed (CCG): shells are horizontally arranged either convex up or convex down; $(\mathrm{H})$ Close-up of the inside of a wave-carved gully on the CCG: it is noticeable that Glycymeris shells are vertically oriented (the yellow chisel marks the horizontal plane reference).
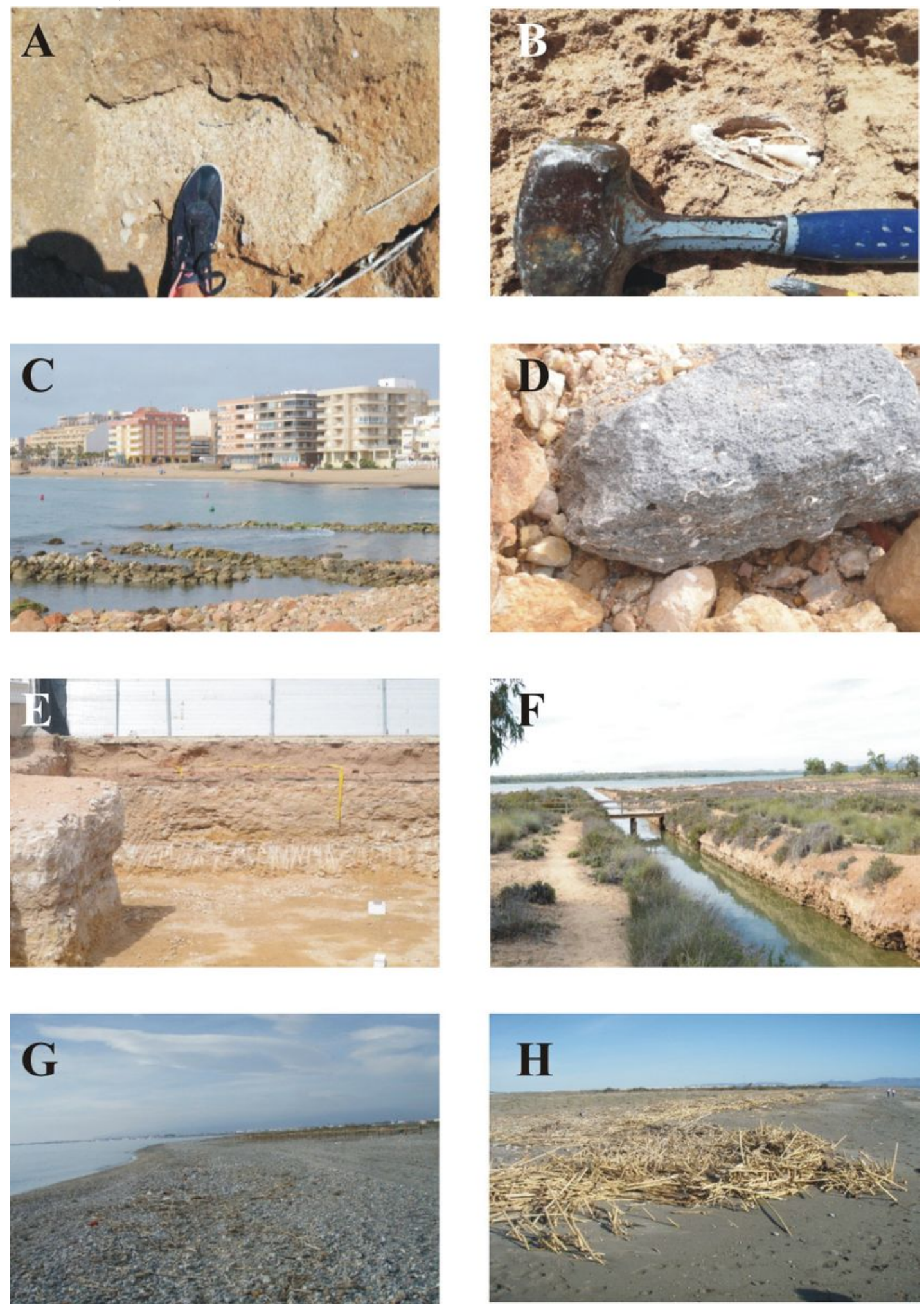

Figure 4 
Representative photos of the Torrevieja-La Mata area: (A) Cemented coquina at CCG with some "alien" elements; (B) Deeply eroded Persististrombus latus shell at CCG; (C) The remains of the Roman Port (LMB-1); (D) Detailed view of Glycymeris shells at LMB-1; (E) Raised marine deposits of La Mata Bar (LMB-2); (F) Holocene sediments at the mouth of El Acequión ditch (LML); the Pleistocene record is below the water level; $(G)$ Beach deposits of El Alquián (Almería) with abundant mollusc shells; the foreground shows plant stems that drifted during the winter surge; $(H)$ Detailed view of stem accumulations; the wave action drove cane stems into the sand body.

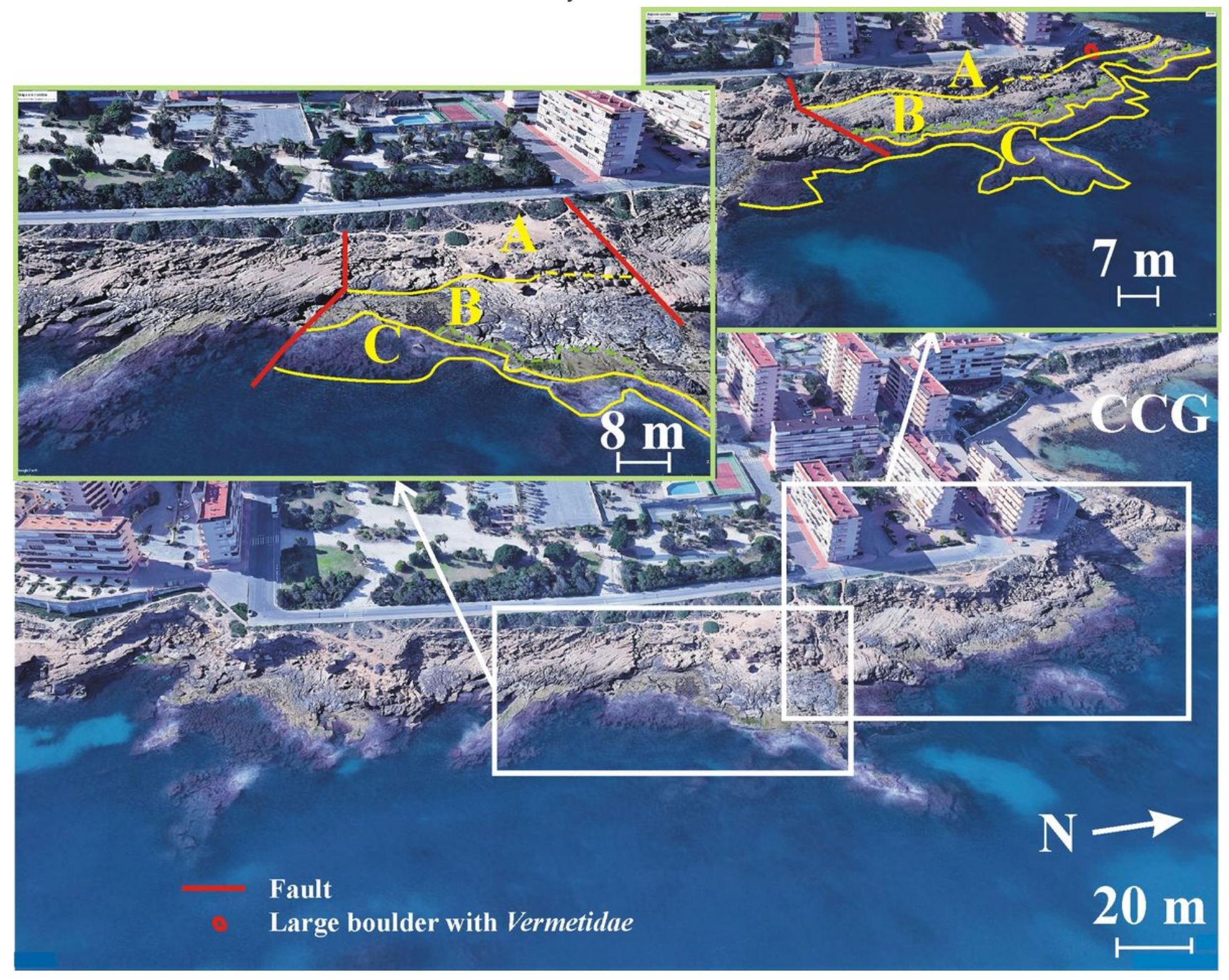

\section{Figure 5}

Picture of Cervera Cape Cliff (CCC) area showing three abrasion surfaces at 4, 1 and $0 \mathrm{~m}$ above sea level ( $A, B, C$ respectively), as well as some faults in the eolian deposits with trough cross-bedding dated at MIS 5. A large boulder with Lithophaga litophaga boreholes and incrusted Vermetidae is marked with a red circle. 


\section{La Mata lagoon}

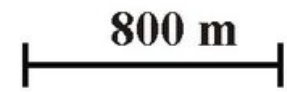

La Mata bar
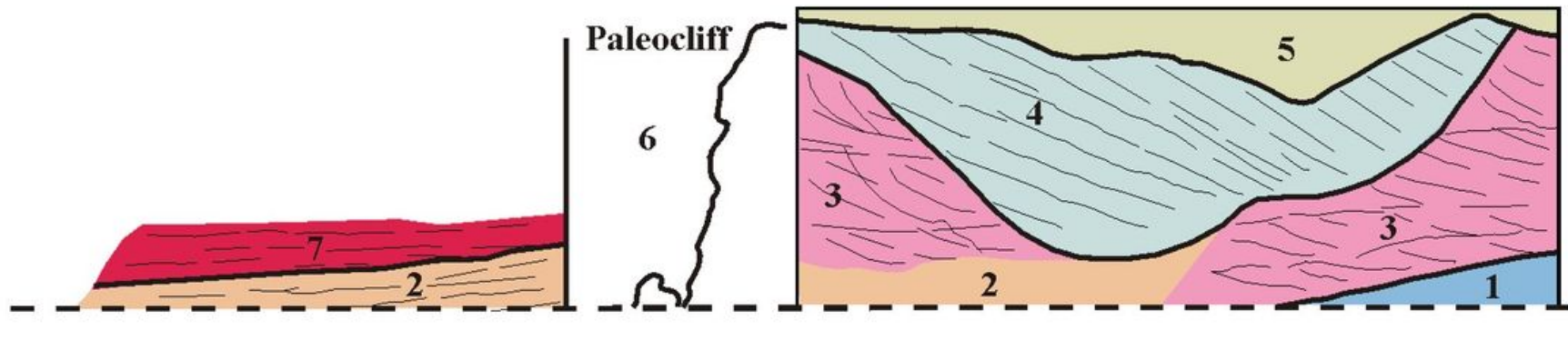

Present day sea level

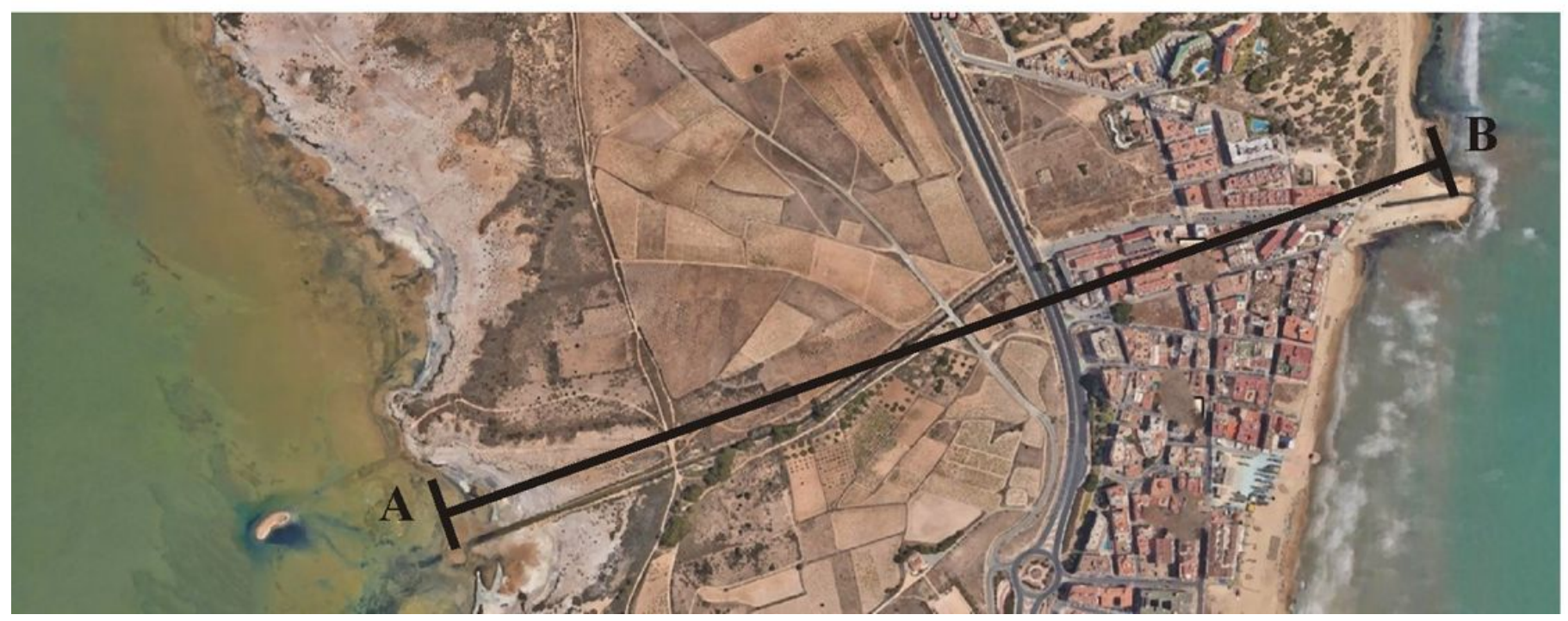

Figure 6

Sketch of the internal sedimentary architecture of section A-B of Fig. 1. A) LML deposits, and B) LMB (modified from Somoza et al., 1986). 1: alluvial deposits; 2: lagoon sediments of MIS 7; 3: bioclastic calcitic sandstone with cosets dipping offshore (LMB-2) of MIS 7; 4: bioclastic calcitic sandstone coset dipping foreshore (LMB-1) of MIS 5; 5: Holocene eolian sands; 6: small erosive paleocliff; 7: Holocene backshore/lagoonal sands dipping landwards with abundant and well-preserved mollusc remains. Note: The designations employed and the presentation of the material on this map do not imply the expression of any opinion whatsoever on the part of Research Square concerning the legal status of any country, territory, city or area o bbnhjr of its authorities, or concerning the delimitation of its frontiers or boundaries. This map has been provided by the authors. 

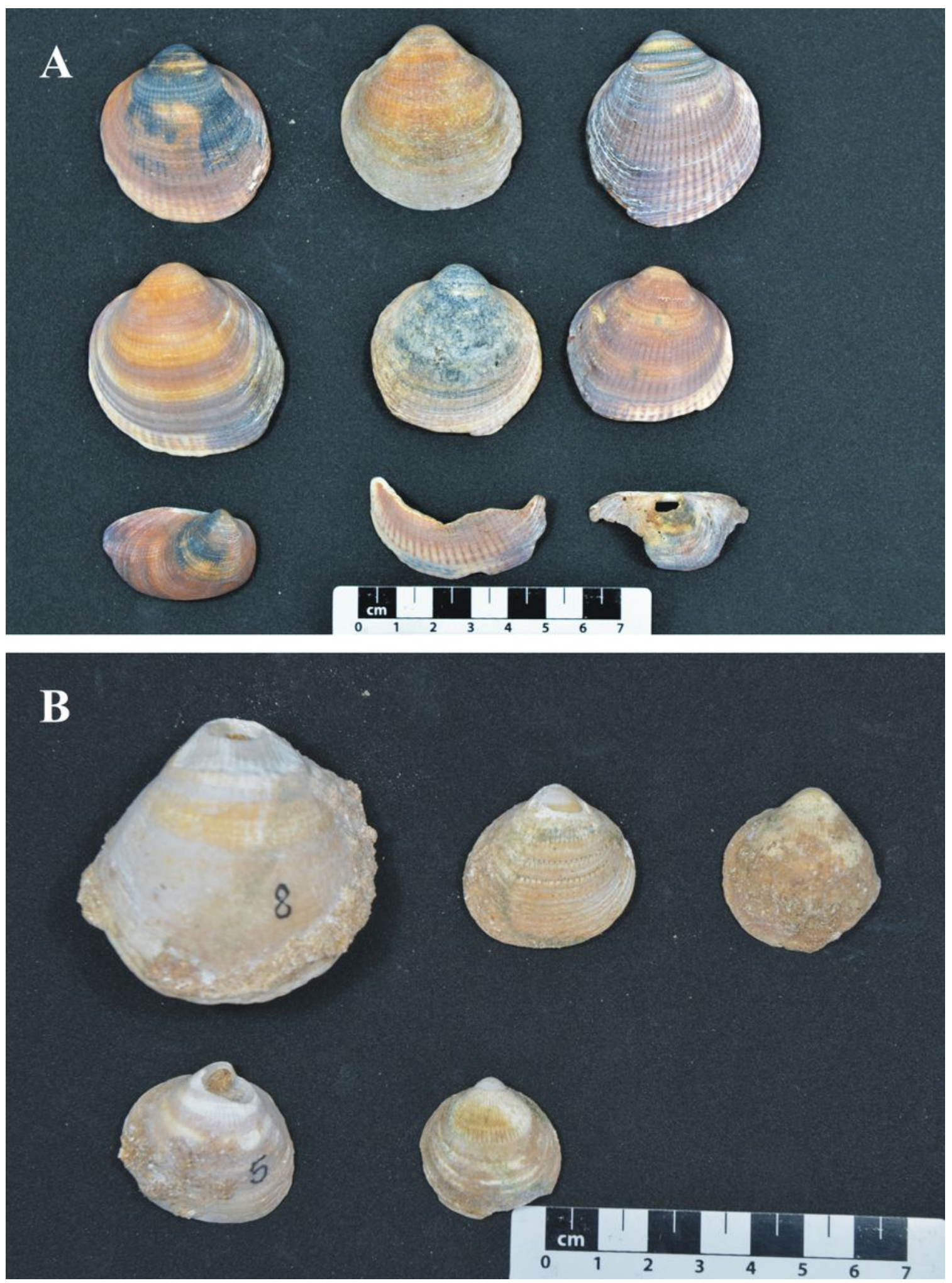

\section{Figure 7}

Pictures showing preservation of Glycymeris shells from A) Recent sediments deposited on El Alquián beach by wave action and B) CCG deposits of MIS 5 originated by a tsunami.

\section{Supplementary Files}


This is a list of supplementary files associated with this preprint. Click to download.

- AARdata.xlsx 